POSTER

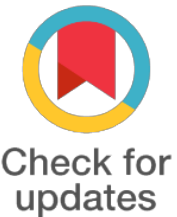

updates
*For correspondence:

venkatoo108@gmail.com

Competing interests: The authors declare that no competing interests exist.

Received: 2017-02-07

Accepted: 2017-08-19

Published: 2017-09-05

Copyright The Author(s) 2017. This article is published with open access by BioMedPress (BMP).

This article is distributed under the terms of the Creative Commons Attribution License (CC-BY 4.0) which permits any use, distribution, and reproduction in any medium, provided the original author(s) and the source are credited.

\section{An in-vitro study to diagnose and distinguish breast and lung cancers using the PCB technology based nanodosimeter}

\author{
Pitchaikannu Venkatraman, C.S.Sureka
}

Department of Medical Physics, Bharathiar University, Coimbatore, Tamil Nadu 641046, India

\section{Abstract}

Generally, in the modern field of nanodosimetry, the Printed Circuit Board (PCB) technology based $3 \mathrm{D}$ positive ion detector has been identified as a device to detect cancers in lungs and breast region. In the nano environment, these cancer cells have been diagnosed by the exhalation of specific volatile organic compounds (VOCs) which serves as eminent source biomarkers for cancer diagnosis. Earlier studies reported that lungs emit various VOCs include Benzene, Ethylbenzene, Cyclohexane, methanol, ethanol, dodecane and tridecane, and the breast emit alkanes, alkenes, ketones, halogenated hydrocarbons, aldehydes, alcohols, esters, unsaturated hydrocarbons, terpenes, siloxanes, and aromates. By employing VOCs exhalation, the field of nanodosimetry aids as a direct evidence that the diagnosis of critical organs like lungs and breast cancer cells without harming the patients is possible. In our present out, we carried out in diagnosing and to distinguishing the cancer tissues of breast and lung using PCB technology based nanodosimeter.

\section{Keywords}

3D Positive lon detector, Breast and lung cancer detection, lon induced impact ionization, VOC.

\section{Funding}

\section{References}

1. V.A. Bashkirov, R.F. Hurley, R.W. Schulte, in NSS/MIC Conference Record, IEEE, 2009, Vol. 694 .

2. Marion Ute Bug, Gerhard Hilgers, Woon Yong Baek, and Hans Rabus, Eur. Phys. J. D (2014)

68: 217 .

3. V.A. Bashkirov, and R.W. Schulte, US9213107 B2, 2009.

4. V.A. Bashkirov, R.F. Hurley, R.W. Schulte, in NSS/MIC Conference Record, IEEE, 2009, Vol. 694 .

5. Margherita Casiraghi, Vladimir Bashkirov, Ford Hurley, and Reinhard Schulte, Eur. Phys. J. D, 2014, 68: 111,

6. M.Casiraghi, V.A. Bashkirov, R.F. Hurley, and R.W. Schulte, Radiat. Prot. Dosim., 2015, pp.1-5. 7. F Vasi, M. Casiraghi, V.A. Bashkirov, R.W. Schulte. JINST 11, 2016, Cog021-Cogo21. 